18. Остапчук С. М. Стандартизація бухгалтерського обліку земель сільськогосподарського призначення / С. М. Остапчук. // Облік і фінанси АПК. - 2012. - №3. - C. 62-71.

19. Пантюхова А. В. Облік земельних ресурсів за міжнародними та національними стандартами з урахуванням екологічної складової. / Пантюхова А. В. // Вісник НТУ «ХПІ». - 2013. - №53 (1026) - С. 96-103.

20. Підвисоцька Л.Я. Облік та звітність земельних ресурсів: проблеми організації та методики / Підвисоцька Л.Я. // Економіка. Управління. Інновації. - 2016. №3 (18).

21. Правдюк Н.Л. Особливості земель сільськогосподарського призначення як об'єкта бухгалтерського обліку / Правдюк Н.Л., Іщенко Я.П. // Збірник наукових праць ВНАУ. Серія: Економічні науки. - 2012. - №1 (56) - С. 211-217.

22. Тлумачення КТМФЗ 5. Права на частки у фондах на виведення з експлуатації, відновлення та екологічну реабілітацію [Електронний ресурс] / Режим доступу: http://zakon.rada.gov.ua/laws/show/929_055\#n2.

23. Соколова Н. Облік договорів оренди: на які зміни звернути увагу [Електронний pecyрc] / Режим доступу: http:/agravery.com/uk/posts/author/show?slug=oblik-dogovorivorendi-na-aki-zmini-zvernuti-uvagu.

24. Карпачова О. МСФЗ 16 «ОРЕНДА» [Електронний ресурс] / Режим доступу: https://zakon.help/article/msfz-16-orenda/

25. Establishment of a land market in Ukraine: current state and prospects [Електронний ресурс] / Режим доступу: file:///C:/Users/Admin/Downloads/2018+Land+market+overview\%20(1).pdf.

* УДК 338.242.2

Іщук Л.І., к.е.н., доцент

Ніколаєва А.М., к.е.н., доцент

Харчук С.В.

Луцький національний технічний університет

\title{
ШЛЯХИ ПОКРАЩЕННЯ ФІНАНСОВОГО СТАНУ ПІДПРИЄМСТВА В СУЧАСНИХ ЕКОНОМІЧНИХ УМОВАХ
}

У статті розкрито сутність поняття фінансового стану підприємства, визначено дестабілізуючі фактори впливу на фінансовий стан та виділено шляхи його покращення.

Ключові слова: фінансовий стан, підприємство, напрям покращення фінансового стану.

* Іщук Л.І., Ніколаєва А.М., Харчук С.В. 


\section{Ishchuk L., Nikolaeva A, Kharchuk S. WAYS TO IMPROVE THE FINANCIAL STATE OF THE ENTERPRISE IN MODERN ECONOMIC CONDITIONS}

The article describes the essence of the concept of the financial state of the enterprise, determines the destabilizing factors of influence on the financial state and identifies the ways of its improvement.

Enterprises operating in a market environment are fully responsible for their obligations to the financial and credit system, their employees, suppliers, the state, as well as the results of production and financial activities. The ability of the enterprise to timely repay its obligations describes its financial condition.

In order to survive enterprises in the conditions of constant intensification of competitive struggle it is necessary to be able to really assess the financial condition of both their enterprise and existing potential competitors. However, first, it is necessary to understand the essence of the term "financial condition".

Financial condition is a complex concept that is the result of the interaction of all elements of the system of financial relations of the enterprise, determined by a set of production and economic factors and is characterized by a system of models, methods and indicators that reflect the availability, allocation and use of financial resources.

If we talk about the factors affecting the financial position of the company, it depends on the results of its production, commercial and financial and economic activities. Therefore, all of the above mentioned activities of the enterprise are influenced by it. Timely detection of destabilizing factors will minimize the risk of deteriorating financial position and reducing profits.

An important way to improve the financial position of Ukrainian enterprises is also to find the optimal ratio of own and borrowed capital, which would provide the minimum financial risk for maximum return on equity. The next direction in improving the financial state of the enterprise may be the production and development of new types of products.

In order to satisfy the financial condition of the enterprise, it is necessary to systematically analyze the finances of the enterprise and eliminate the existing shortcomings. A system of measures to maintain a high financial standing should include:

- permanent monitoring of the external and internal conditions of the enterprise;

- development of measures to reduce the external vulnerability of the enterprise;

- development of preparatory plans in case of emergencies, implementation of preliminary measures for their provision;

- implementation of plans of practical measures in the event of a crisis situation, the adoption of risky and non-standard decisions in case of deviation of the situation;

- coordination of actions of all participants and control over the implementation of activities and their results.

It is under such conditions that it is possible to provide a monitoring system for each of the components of a positive financial state of enterprises, which would be able to optimize it in accordance with the development prospects.

Key words: financial status, enterprise, direction of improvement of financial condition. 
Ищук Л.И., Николаева А.Н., Харчук С.В.

ПУТИ УЛУЧШЕНИЯ ФИНАНСОВОГО СОСТОЯНИЯ ПРЕДПРИЯТИЯ В СОВРЕМЕННЫХ ЭКОНОМИЧЕСКИХ УслОВИЯХ

В статье раскрыта сущность понятия финансового состояния предприятия, определены дестабилизирующие факторы влияния на финансовое состояние и выделены пути его улучшения.

Ключевые слова: финансовое состояние, предприятие, пути улучшения финансового состояния.

Постановка проблеми у загальному вигляді та її зв'язок 3 важливими науковими та практичними завданнями. Підприємства, які працюють в ринкових умовах, несуть повну відповідальність за своїми зобов'язаннями перед ланками фінансово-кредитної системи, власними працівниками, постачальниками, державою, а також за результатами виробничо-фінансової діяльності. Здатність підприємства своєчасно погашати свої зобов'язання характеризує його фінансовий стан.

Для виживання підприємствам в умовах постійного загострення конкурентної боротьби необхідно вміти реально оцінити фінансовий стан як свого підприємства, так й існуючих потенційних конкурентів.

Аналіз останніх досліджень, у яких започатковано вирішення проблеми. Визначенню шляхів покращення фінансового стану підприємства присвятили свої роботи такі вчені: Лігоненко Л.О., Непочатенко О.О., Сергеєв І.В., Л. Білик, Л. Буряк, О. Барановський, О. Василик, К. Ізмайлова, Т. Ковальчук, Л. Лахтіонова, А. Поддєрьогін, О. Терещенко, С. Шкарабан, М. Яцків та ін. Вагомий внесок у дослідженнях напрямів оцінки фінансової стану підприємства зробили такі вчені-економісти: Бандурка O.М., Коробов М.Я., Грабовецький Б.С., Обушак Т.А., Цар О.3., Покропивний С.Ф. та інші.

Цілі статті. Метою написання даної статті $є$ пошук та обгрунтування шляхів покращення фінансового стану підприємств в сучасних умовах.

Виклад основного матеріалу дослідження 3 повним обгрунтуванням. Фінансовий стан підприємства $є$ важливою характери- 
стикою результатів діяльності будь-якого підприємства, яка визначається взаємодією всіх його складових елементів та включає сукупність виробничо-господарських факторів. Думки науковців стосовно трактування сутності даного визначення зводяться до необхідності регулярного проведення його діагностики для забезпечення беззбиткової діяльності.

Фінансовий стан підприємства - це сутнісна характеристика його діяльності в певний період, яка визначає реальну та потенційну можливість підприємства забезпечувати достатній рівень фінансування фінансово-господарської діяльності.

Якщо говорити про фактори впливу на фінансовий стан підприємства, то він залежить від результатів його виробничої, комерційної та фінансово-господарської діяльності. Тому на нього впливають усі вище згадані види діяльності підприємства. Своєчасне виявлення дестабілізуючих чинників дозволить мінімізувати ризик погіршення фінансового стану та зменшення прибутку. На рис. 1 відображено внутрішні та зовнішні дестабілізуючі фактори впливу на фінансовий стан підприємств.

Важливим шляхом покращання фінансового стану українських підприємств є пошук оптимального співвідношення власного і позикового капіталу, яке б забезпечило мінімальний фінансовий ризик за максимальної рентабельності власного капіталу. Цей процес реалізується за допомогою оперативного механізму фінансової стабілізації - системи заходів, спрямованих, 3 одного боку, на зменшення фінансових зобов'язань, а з іншого, на збільшення грошових активів, що забезпечують ці зобов'язання [5, c. 134].

В умовах конкурентного середовища актуальності набуває оптимізація збутової політики підприємства. Підприємству необхідно активізувати політику в галузі маркетингу з метою просування своєї продукції, яка фактично за рахунок високої якості та ціни, нижчої від середньо галузевої є конкурентоспроможною.

Доцільно також звернути увагу на те, що для покращання свого фінансового становища виробники товарів та послуг повинні реалізовувати всю продукцію, що застоюється на складах. 
Економічні науки". - Серія "Облік і фінанси". - Випуск 15 (57). - 2018.

Дестабілізуючі фактори впливу на фінансовий стан підприємства

\begin{tabular}{|c|c|}
\hline Внутрішні & Зовнішні \\
\hline $\begin{array}{l}\text { 1. Відсутність маркетингової } \\
\text { стратегії } \\
\text { 2. Недосконала організаційна } \\
\text { структура } \\
\text { 3. Наявність зношених основ- } \\
\text { них засобів } \\
\text { 4. Відсутність інвестиційних } \\
\text { проектів } \\
\text { 5. Прорахунки в собівартості та } \\
\text { ціні продукції } \\
\text { 6. Наявність прострочених } \\
\text { кредитів }\end{array}$ & $\begin{array}{l}\text { 1. Інфляція } \\
\text { 2. Девальвація національної } \\
\text { грошової одиниці } \\
\text { 3. Ріст відсоткових ставок на } \\
\text { фінансовому ринку } \\
\text { 4. Зменшення платоспромож- } \\
\text { ності населення } \\
\text { 5. Наявність конкурентів } \\
\text { 6. Необгрунтована цінова полі- } \\
\text { тика держави } \\
\text { 7. Низька конкурентоспромо- } \\
\text { жність на іноземних ринках }\end{array}$ \\
\hline
\end{tabular}

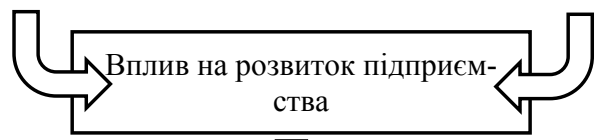

1. Низька ліквідність активів

2. Неспроможність вчасно розрахуватись за своїми зобов'язаннями

3. Залежність від зовнішніх джерел фінансування (кредиторів)

4. Наявність значних запасів готової продукції на складах

5. Уповільнення обертання фінансових ресурсів

6. Зменшення продуктивності праці

7. Збитковість основної діяльності

8. Низький рівень рентабельності та ефективності діяльності

9. Погіршення ділової репутації та інвестиційної привабливості

10. Наявність ризику банкрутства

Рис. 1. Дестабілізуючі фактори впливу на фінансовий стан підприємства

Для розширення ринків збуту підприємство може створити пункти роздрібної торгівлі. Це призведе до збільшення прибутку та збільшення оборотності капіталу. Впровадження цього проекту звичайно ж не вирішує існуючих фінансових проблем, але дозво- 
лить скоротити термін реалізації товару та прискорити розрахунки 3 кредиторами.

Ще одним напрямком покращання фінансового стану підприємства $є$ збільшення грошових коштів на розрахунковому рахунку підприємства, що збільшить коефіцієнт абсолютної ліквідності і дозволить підприємству брати довго- i короткострокові позики в банку для фінансування поточної діяльності, які видаються лише платоспроможним підприємствам, в яких коефіцієнт абсолютної ліквідності відповідає нормі. Збільшення грошових коштів можна забезпечити за рахунок реалізації зайвих виробничих і невиробничих фондів, здачі їх в оренду [2].

Наступним напрямком покращання фінансового стану підприємства може стати виробництво і розробка нових видів продукції, яка зацікавить споживачів, а також отримання ліцензій на виробництво «ходових» товарів, що дасть змогу стабілізувати і покращити фінансовий стан підприємства.

Слід відмітити, що фінансовий стан підприємства не може бути стійким, якщо воно не отримує прибутку у розмірах, що забезпечують необхідний приріст фінансових ресурсів, спрямованих на зміцнення матеріально-технічної бази підприємства та їх соціальної сфери [4].

Висновки. За результатами аналізу фінансового стану виявляються прогалини в діяльності підприємств та в результаті цього здійснюється пошук резервів покращення. I згідно до цього визначаються альтернативні управлінські рішення i напрями їх реалізації. Відтак, процес аналізу фінансового стану підприємства це система, яка включає аналіз середовища функціонування, процесу планування і контролю за діяльністю підприємства, що дозволить робити іiі прибутковою. В цілому підсумовуючи вище зазначене варто свідчити, що від правильності вибору та ходу реалізації управлінських рішень залежить поточний фінансовий стан та напрямки його покращення в перспективі.

1. Аверіна М.Ю. Аналіз та оцінка фінансового стану підприємства: шляхи покращення М. Ю Аверіна // Актуальні проблеми економіки. - 2012. - № 9. - С. 92-100

2. Безбородова Т.В. Сутність та необхідність аналізу фінансового стану // Економіка. Управління. Інновації. Випуск № 1 (11) - 2014. - С. 1-7. 
Економічні науки". - Серія "Облік і фінанси". - Випуск 15 (57). - 2018.

3. Конєва Н.О., Шаповалова I.О. Шляхи покращення фінансового стану підприємств [Електронний ресурс] - Режим доступу: http://mdu.edu.ua/spaw2/uploads/files/16_13.pdf.

4. Кулик Л.С. Діагностика фінансового стану підприємства як основа його економічної безпеки. Зб. наук. пр. «Економічні науки». - Серія «Облік і фінанси». - Луцьк: ЛНТУ, 2017.

5. Рудницька О.М., Біленська Я.Р. Шляхи покращення фінансового стану українських підприємств / Рудницька О.М., Біленська Я.А. // Вісник «Логістика», Львів: Вид-во НУ ЛП, 2013. - № 649 - С. 132-138.

6. Цар О.З. Аналіз динаміки фінансового стану підприємства України / О.3. Цар // Зовнішня торгівля: економіка, фінанси, право. - 2016. - №3. - С.221-238.

*УДК 65.041.1:338.48

Квасній Л.Г., к.е.н, доцент

Дрогобицький державний педагогічний університет ім. I. Франка

Щербан О.Я., к.е.н, доцент

ВСП НН ІППТ НУ «Львівська політехніка»

\section{ЧИННИКИ АНТИКРИЗОВОГО УПРАВЛІННЯ ПІДПРИЄМСТВ ТУРИСТИЧНОї ІНДУСТРІї}

У статті проаналізовано сучасний стан розвитку та проблеми туристичної діяльності в Україні. Обгрунтовано доцільність застосування антикризового управління на вітчизняних підприємствах туристичної індустрії. Запропоновано антикризові заходи розвитку туризму, що сприятимуть вирішенню наявних проблем.

Ключові слова: кризовий стан, антикризове управління, туристична галузь.

Kvasniy L., Shcherban O.

\section{FACTORS OF ANTI-CRISIS MANAGEMENT OF ENTERPRISES OF THE TRAVEL INDUSTRY}

The purpose of the article is to study anticrisis management of tourist organizations and enterprises as a means of forming their competitive advantages on different levels of management. As a result of analysis and generalization of studies conducted by domestic and foreign scholars, the main features of the development of tourism were determined, main directions of improving the competitiveness of tourism activities were systematized and crisis management measures for tourism enterprises

* Квасній Л.Г., Щербан О.Я. 